\title{
Taxus globosa Schltdl. (Taxaceae). Distribution and Diagnosis of an Endangered Yew
}

\author{
Javier López-Upton ${ }^{1}$, Xavier Garcia-Martí ${ }^{2}$ \\ ${ }^{1}$ Postgrado en Ciencias Forestales, Colegio de Postgraduados, Campus Montecillo, Texcoco, México \\ ${ }^{2}$ Bioma Forestal, C / Zumedia, Etxauri, Navarra, Spain
}

Email address:

jlopezupton@gmail.com (J. López-Upton),xavi@biomaforestal.es (X. Garcia-Martí)

\section{To cite this article:}

Javier López-Upton, Xavier Garcia-Martí. Taxus globosa Schltdl. (Taxaceae). Distribution and Diagnosis of an Endangered Yew. Earth Sciences. Special Issue: Conservation of Taxus Baccata Linn (Yew). Vol. 4, No. 3-1, 2015, pp. 80-88. doi: 10.11648/j.earth.s.2015040301.13

\begin{abstract}
After prospecting the vast majority of the populations and consulting herbarium collections and literature, data of distribution and demography of the Mexican populations of Taxus globosa is presented. Besides, the global distribution as the status of the species and its ecology is reviewed. Some populations are well preserved, however most of the prospected populations are under risk of anthropogenic disturbances. No real direct use of the species is performed, but other activities put pressure in their very small populations. With the data compiled, a preliminary diagnosis of its natural state is exposed towards the management and conservation of the species.
\end{abstract}

Keywords: Anthropogenic Disturbances, Conservation Ecology, Global Distribution, Mesoamerica, Mexican Yew, T. globosa

\section{Introduction}

The genus Taxus L. (Taxaceae) is distributed almost entirely throughout the northern hemisphere. The existence of four Taxus species is widely recognized in the American continent [1]. In the northernmost area of North America, T. Canadensis inhabits the Atlantic Coast of USA and Canada, while $T$. brevifolia is on the Pacific coast. T. floridana or T. globosa var. floridana sensu Spjut [2] - is located in the Apalachicola River Basin, a species displaying very restricted distribution at specific locations within the State of Florida [3]. Finally, the species considered as the subject of this work, T. globosa Schltdl. is one of the least studied species that inhabits the southernmost area, specifically in cloud forests located in Mexico and to the north of Central America [4].

This species, more widely known as Mexican Yew, has a disjoint distribution in Mexico along the length of the Sierra Madre Oriental (in the States of Nuevo León, Tamaulipas and San Luis Potosí, Querétaro, Hidalgo, Puebla and Veracruz) and the Juarez Sierra in Oaxaca and the sierras of Chiapas. Knowledge about the actual distribution of Mexican Yew is more diffuse and the size of its populations is much smaller in the Neotropical biogeographic region. There are numerous records with as little as 30-40 individuals per population in Sierra Juárez in Oaxaca. T. globosa herbarium specimens have been found in cloud forests belonging to Los Altos de Chiapas
[5]. This yew also lives in Guatemala's humid montane forests $[6,7]$ located at Las Minas Biosphere Reserve, Sierra de los Cuchumatanes and the Volcanic Chain. In El Salvador, very small nuclei are residually located in remote areas near to the top of Cerro del Pital [8] at 2,670 m (ASL). A few kilometres away towards the west, in Honduras, the species lives in Santa Bárbara National Park, in addition to several locations inside the Celaque National Park, a place considered as the southernmost limit of its global distribution [22].

\section{Morphological and Autoecological Nature}

T. globosa is a tree that does not exceed $15 \mathrm{~m}$ in height and $60 \mathrm{~cm}$ in trunk diameter; so, it is a smaller species than $T$. baccata, and more related to the rest of the American species along the Eastern seaboard, such as the shrub-like $T$. canadensis. For the American plant, the needles are more shiny, elongated and acuminate at the apex, with a more visible dark green colour along the middle nerve areas and underside margins. The aril and seed are the $T$. globosa hallmark, these are more rounded and compressed; this is why, in 1838, Diederichvon Schlechtendal described it as Taxus baccata var. globosa [9]. The species grows preferably on well drained, acidic soils, rich in inorganic matter. The altitudinal range of distribution fluctuates from1,100 to 2,960 
$\mathrm{m}$ (ASL). The highest altitude is found in the cloud forests of Oaxaca exceeding 2,600 $\mathrm{m}$ (ASL) which is the maximum altitude reached by T. baccata in the High Atlas of Morocco $[10,11]$.

One of the most notable autecological features of Mexican Yew is its distinctly nemoral nature. T. globosa occurs exclusively in sheltered and shady bottoms of canyons that shows permanent or seasonal standing water; the species presence depends on the canopy above filtering out a large amount of the direct solar radiation. The species needs an annual rainfall over $800 \mathrm{~mm}$ but which can exceed 2,500 $\mathrm{mm}$. For example, in forests of the State of Hidalgo, where we detected a recent expansion of the species, yew inhabits a temperate and sub-humid climate under a canopy of Abies religiosa (Kunth) Schltdl. \& Cham. This protective cover significantly reduces evapotranspiration rates inside the forest. In this area, rainfall ranges from 1,000 to $1,200 \mathrm{~mm}$ excluding horizontal precipitation that should increase considerably the total amount. The average annual temperature in those well preserved forests is $14^{\circ} \mathrm{C}$ [4].

\section{T. globosa Habitat}

The Mexican yew woods are characterized by their distribution within a broad and discontinuous latitudinal gradient. They are isolated by lower and warmer areas including semi-desert areas. Usually, these formations record a high orographic precipitation, mild climate and high floristic complexity that varies even between nearby sites [12]. For example, Luna-Vegaet al. [13] describes these forests as typical vegetal communities that exist in temperate zones, where there is a subordinated floristic element of subtropical nature. Structural formations coexisting with yew in Mexico are mixed pine-oak forests: Pinus pseudostrobus, $P$. ayacahuite, P. patula, Arbutus xalapensis, Quercus crassifolia, Q. germana, Q. rysophylla, Q. laurina and Tilia mexicana among many others and fir forests (Abies religiosa and $A$. vejarii). The yew also occurs in cloud forests alongside species belonging to this type of formations such as Ostrya virginiana, Liquidambar styraciflua, Cornus disciflora to name some widely distributed species [9, 13, 14]. In Mesoamerican montane forests (located at southern Mexico, Guatemala, Honduras and El Salvador), the species is typically associated with Pinus ayacahuite and Abies guatemalensis [7].

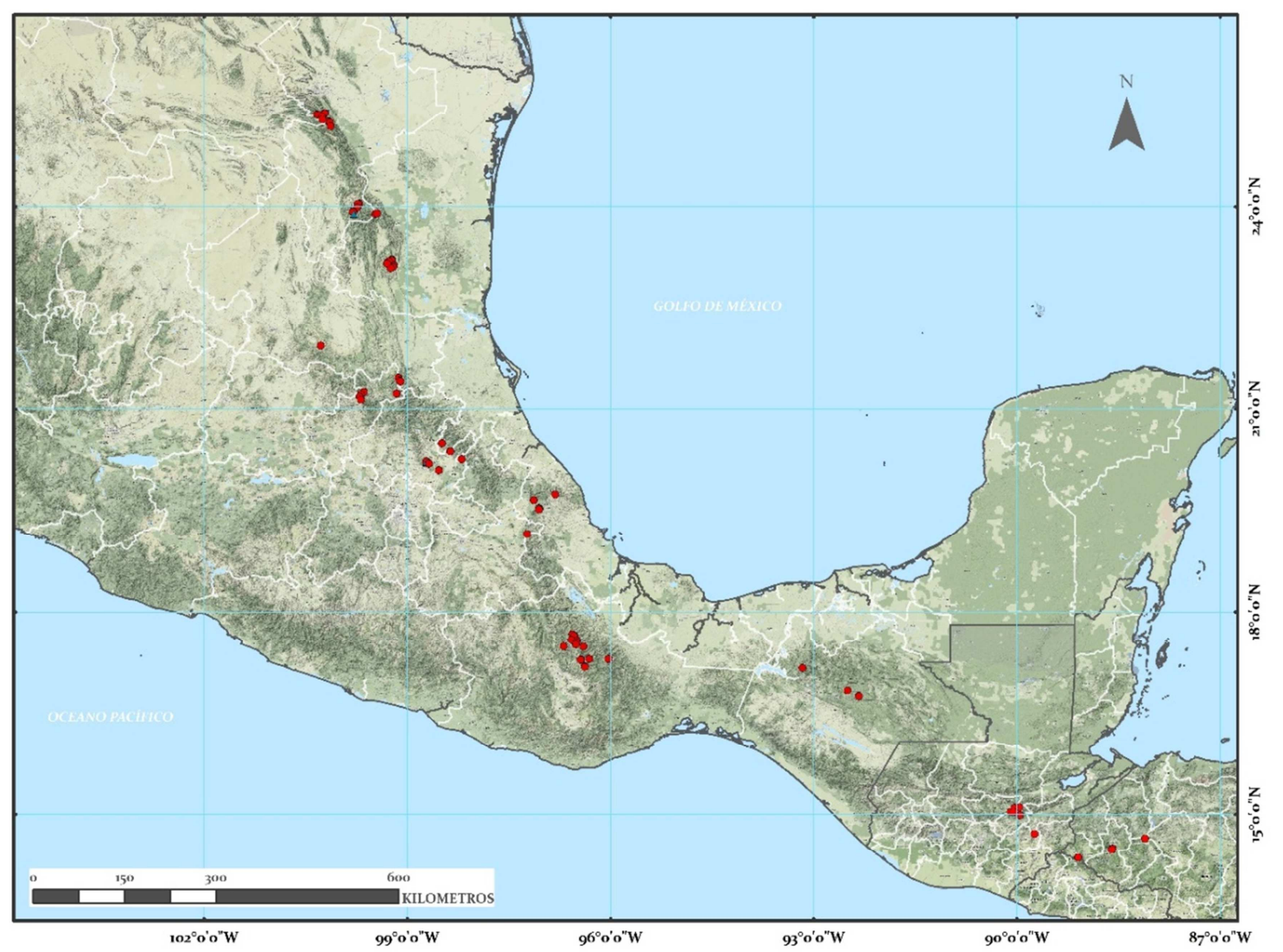

Figure 1. Global distribution of T. globosa.

\section{Methodology}

After reviewing herbarium collections, analysing related literature, and several interviews in local communities, a complete census of T. globosa in Mexico is achieved. In 29 of these populations we made a survey and in situ characterization, gathering data about number of individuals, geographic location, altitude, regeneration recruitment and other parameters. With this information the conservation value of each location (classified as favourable, inadequate and unfavourable) was created following a model already tested 
for T. baccata [33]. After this, an analysis of the data collected was performed in order to offer a wide view from ecological aspects and the conservation of the species and its habitat. Further, geographic data was gathered to create a map of the natural distribution of $T$. globosa including the localization of the species in Guatemala, Honduras and El Salvador (Figure $1)$.

\section{Results and Discussions}

To date, in the Mexican territory, a total of 75 populations of T. globosa have been located in Mexico (Table 1). The vast majority of these nuclei contain less than 100 adult individuals. From the 29 characterized and inventoried populations, only 11 of them showed spontaneous regeneration and its overall proportion of male/female individuals is approximately $1 / 1.3$ [15]. 12 of these characterized populations were considered under favourable condition, 12 unfavourable and 5 with inadequate information (Table 2). Consequently, we can say that demographic bottlenecks, that require a more detailed and specific study, are frequent. However, there are a few yew stands that currently exhibit a remarkable regeneration due to diminished human intervention and their difficult access. These are roughly focused in at least two large areas: one is located in the central and southern area of Nuevo León in north-eastern Mexico, including many nuclei within the municipalities of Zaragoza and Santiago. Here there are $T$. globosa populations with many individuals registered in a census: Las Tinajas with 3,035 individuals and Potrero Redondo with 3,460 [14]. These same authors conducted a demographic study in several northern populations that included a classification by forest mensuration with class intervals (height-diameter) that allows inference of the inter-annual evaluation of the recruitment dynamics, as well as disturbance changes that occurred in a spatio-temporal scale for the studied yew populations. The second zone is located hundreds of miles towards the south and represents what might constitute a set of meta-populations distributed in the headwaters of the deepest valleys that define El Chico National Park in Hidalgo. This zone is located in the central-eastern area of Mexico and includes populations showing abundant regeneration such as those located in two ravines: "Cañada Los Ayacahuites"and "Pueblo Nuevo Canyon", each of them with next to 150 mature trees in a very well preserved area.

\subsection{Key Mechanisms of Ecological Interaction}

Once some of the more "healthy" Mexican Yew stands in ideal situations were pinpointed, one wonders, what could be the factors involved in the success of its establishment? The average production of fruits per tree for T. globosa is very limited: 40-50 seeds/adult female per year [16]. This fact was subsequently confirmed from seed collection from multiple locations and across years. Mast year occurred every two and three year, and some trees do not have any seed in a year. This circumstance may be due to the purely shade-tolerant nature (sciophilous) of the species in the sense of [32] who detected that lack of light causes a decreasing production of flowers in some European yew populations. Seed viability has been investigated using the tetrazolium test to analyze the seed viability from different populations $[15,17]$ and those obtained in 2011 for the present work. The maximum percentages of viable seed obtained globally were $98 \%, 75 \%$ and just $21 \%$ respectively. Further, germination capacity is very low especially in the stands from central Mexico [17]. Thus, in these vigorous yew stands, a successful recruitment of new individuals, having so little seed rain and fluctuating viability values, is a fact that catches the eye, especially when it is compared to European species that easily reach seed production averaging several thousand seeds per individual per year.

Table 1. Located populations of Taxus globosa in Mexico.

\begin{tabular}{|c|c|c|c|c|c|}
\hline $\mathbf{N}^{\mathbf{0}}$ & Population & State & Latitude & Longitude & Height (msnm) \\
\hline 1 & La Ciénega & Nuevo León & $25^{\circ} 22^{\prime} 35^{\prime \prime}$ & $100^{\circ} 13^{\prime} 15^{\prime \prime}$ & 1460 \\
\hline 2 & El Manzano & Nuevo León & $25^{\circ} 22^{\prime} 29^{\prime \prime}$ & $100^{\circ} 12^{\prime} 39^{\prime \prime}$ & 1460 \\
\hline 3 & El Manzano-VitroParque & Nuevo León & $25^{\circ} 22^{\prime} 27^{\prime \prime}$ & $100^{\circ} 13^{\prime} 05^{\prime \prime}$ & 1470 \\
\hline 4 & El Cilantrillo & Nuevo León & $25^{\circ} 21^{\prime} 15^{\prime \prime}$ & $100^{\circ} 20^{\prime} 00^{\prime \prime}$ & 1890 \\
\hline 5 & San Isidro & Nuevo León & $25^{\circ} 20^{\prime} 50^{\prime \prime}$ & $100^{\circ} 18^{\prime} 15^{\prime \prime}$ & 2055 \\
\hline 6 & El Tejocote & Nuevo León & $25^{\circ} 19^{\prime} 20^{\prime \prime}$ & $100^{\circ} 15^{\prime} 30^{\prime \prime}$ & 1970 \\
\hline 7 & La Camotera & Nuevo León & $25^{\circ} 16^{\prime} 45^{\prime \prime}$ & $100^{\circ} 15^{\prime} 10^{\prime \prime}$ & 1760 \\
\hline 9 & La Trinidad & Nuevo León & $25^{\circ} 14^{\prime} 00^{\prime \prime}$ & $100^{\circ} 08^{\prime} 30^{\prime \prime}$ & 1400 \\
\hline 10 & El Butano & Nuevo León & $25^{\circ} 10^{\prime} 50^{\prime \prime}$ & $100^{\circ} 08^{\prime} 00^{\prime \prime}$ & 2000 \\
\hline 11 & Cañada Agua Fría & Nuevo León & $24^{\circ} 02^{\prime} 20^{\prime \prime}$ & $99^{\circ} 42^{\prime} 50^{\prime \prime}$ & 1890 \\
\hline 12 & Cañada La Era & Nuevo León & $24^{\circ} 02^{\prime} 15^{\prime \prime}$ & $99^{\circ} 44^{\prime} 05^{\prime \prime}$ & 2350 \\
\hline 13 & Cerro El Viejo & Nuevo León & $23^{\circ} 59^{\prime} 10^{\prime \prime}$ & $99^{\circ} 44^{\prime} 30^{\prime \prime}$ & 2375 \\
\hline 14 & La Yerbabuena & Nuevo León & $23^{\circ} 55^{\prime} 31^{\prime \prime}$ & $99^{\circ} 47^{\prime} 58^{\prime \prime}$ & 2100 \\
\hline 15 & La Encantada & Nuevo León & $23^{\circ} 55^{\prime} 20^{\prime \prime}$ & $99^{\circ} 48^{\prime} 20^{\prime \prime}$ & 2385 \\
\hline 18 & Galindo & Tamaulipas & $23^{\circ} 54^{\prime} 00^{\prime \prime}$ & $99^{\circ} 27^{\prime} 00^{\prime \prime}$ & 2300 \\
\hline 19 & Los Caballos-Puerto Purificación & Tamaulipas & $24^{\circ} 04^{\prime} 00^{\prime \prime}$ & $99^{\circ} 27^{\prime} 00^{\prime \prime}$ & 1245 \\
\hline 20 & Reserva "El Cielo" N & Tamaulipas & $23^{\circ} 12^{\prime} 25^{\prime \prime}$ & $99^{\circ} 13^{\prime} 35^{\prime \prime}$ & 1550 \\
\hline 21 & Reserva "El Cielo" S & Tamaulipas & $23^{\circ} 11^{\prime} 46^{\prime \prime}$ & $99^{\circ} 13^{\prime} 43^{\prime \prime}$ & 1620 \\
\hline 22 & Joya de Salas & Tamaulipas & $23^{\circ} 10^{\prime} 48^{\prime \prime}$ & $99^{\circ} 16^{\prime} 26^{\prime \prime}$ & 1650 \\
\hline
\end{tabular}




\begin{tabular}{|c|c|c|c|c|c|}
\hline $\mathbf{N}^{0}$ & Population & State & Latitude & Longitude & Height (msnm) \\
\hline 23 & Los Tres Cerritos & Tamaulipas & $23^{\circ} 07^{\prime} 10^{\prime \prime}$ & $99^{\circ} 12^{\prime} 00^{\prime \prime}$ & 1350 \\
\hline 24 & Rancho El Cielo & Tamaulipas & $23^{\circ} 07^{\prime} 00^{\prime \prime}$ & $99^{\circ} 12^{\prime} 00^{\prime \prime}$ & 1450 \\
\hline 25 & Ojo de Agua del Indio & Tamaulipas & $23^{\circ} 05^{\prime} 45^{\prime \prime}$ & $99^{\circ} 12^{\prime} 40^{\prime \prime}$ & 1430 \\
\hline 26 & Sierra de Guatemala & Tamaulipas & $23^{\circ} 09^{\prime} 00^{\prime \prime}$ & $99^{\circ} 18^{\prime} 00^{\prime \prime}$ & 1550 \\
\hline 27 & San José & Tamaulipas & $23^{\circ} 04^{\prime} 48^{\prime \prime}$ & $99^{\circ} 13^{\prime} 40^{\prime \prime}$ & 1340 \\
\hline 28 & Casa de Piedra & Tamaulipas & $23^{\circ} 02^{\prime} 48^{\prime \prime}$ & $99^{\circ} 14^{\prime} 50^{\prime \prime}$ & 1400 \\
\hline 29 & Arroyo del Tepaxtle & San Luis Potosí & $21^{\circ} 55^{\prime} 40^{\prime \prime}$ & $100^{\circ} 16^{\prime} 40^{\prime \prime}$ & 2000 \\
\hline 30 & Cañada de las Avispas & Querétaro & $21^{\circ} 27^{\prime} 26^{\prime \prime}$ & $99^{\circ} 07^{\prime} 48^{\prime \prime}$ & 1980 \\
\hline 31 & Cerro Grande & Querétaro & $21^{\circ} 25^{\prime} 00^{\prime \prime}$ & $99^{\circ} 07^{\prime} 00^{\prime \prime}$ & 2300 \\
\hline 32 & Llano Chiquito & Querétaro & $21^{\circ} 24^{\prime} 30$ & $99^{\circ} 07^{\prime} 30^{\prime \prime}$ & 2120 \\
\hline 33 & El Salto & Querétaro & $21^{\circ} 14^{\prime} 50^{\prime \prime}$ & $99^{\circ} 38^{\prime} 30^{\prime \prime}$ & 2200 \\
\hline 34 & La Joya del Hielo & Querétaro & $21^{\circ} 13^{\prime} 30^{\prime \prime}$ & $99^{\circ} 09^{\prime} 35^{\prime \prime}$ & 1900 \\
\hline 35 & Cañada Los Granadillos & Querétaro & $21^{\circ} 12^{\prime} 40^{\prime \prime}$ & $99^{\circ} 41^{\prime} 00^{\prime \prime}$ & 2400 \\
\hline 36 & Barranca El Bosque & Querétaro & $21^{\circ} 09^{\prime} 40^{\prime \prime}$ & $99^{\circ} 40^{\prime} 44^{\prime \prime}$ & 2.600 \\
\hline 37 & Cañada de Agua Fría & Querétaro & $21^{\circ} 08^{\prime} 14^{\prime \prime}$ & $99^{\circ} 41^{\prime} 06^{\prime \prime}$ & 2620 \\
\hline 38 & Agua Blanca Cerro & Hidalgo & $20^{\circ} 22^{\prime} 01^{\prime \prime}$ & $98^{\circ} 20^{\prime} 22^{\prime \prime}$ & 2260 \\
\hline 39 & El Remudadero & Hidalgo & $20^{\circ} 22^{\prime} 00^{\prime \prime}$ & $98^{\circ} 19^{\prime} 00^{\prime \prime}$ & 2250 \\
\hline 40 & Cañada Los Zorrillos & Hidalgo & $20^{\circ} 13^{\prime} 16^{\prime \prime}$ & $98^{\circ} 43^{\prime} 08^{\prime \prime}$ & 2400 \\
\hline 41 & Cañada Los Ayacahuites & Hidalgo & $20^{\circ} 12^{\prime} 25^{\prime \prime}$ & $98^{\circ} 43^{\prime} 10^{\prime \prime}$ & 2.630 \\
\hline 42 & Los Corrales-El Chico & Hidalgo & $20^{\circ} 12^{\prime} 13^{\prime \prime}$ & $98^{\circ} 43^{\prime} 33^{\prime \prime}$ & 2550 \\
\hline 43 & El Conejo & Hidalgo & $20^{\circ} 12^{\prime} 11^{\prime \prime}$ & $98^{\circ} 43^{\prime} 28^{\prime \prime}$ & 2500 \\
\hline 44 & Pueblo Nuevo & Hidalgo & $20^{\circ} 11^{\prime} 04^{\prime \prime}$ & $98^{\circ} 40^{\prime} 42^{\prime \prime}$ & 2.530 \\
\hline 45 & Cuyamalolla & Hidalgo & $20^{\circ} 05^{\prime} 23^{\prime \prime}$ & $98^{\circ} 32^{\prime} 04^{\prime \prime}$ & 2650 \\
\hline 46 & Barranca Rio Seco & Hidalgo & & & 2630 \\
\hline 47 & Estación de Honey & Puebla & $20^{\circ} 15^{\prime} 00^{\prime \prime}$ & $98^{\circ} 12^{\prime} 00^{\prime \prime}$ & 2000 \\
\hline 48 & El Salto, Helechales, & Veracruz & $20^{\circ} 36^{\prime} 00^{\prime \prime}$ & $98^{\circ} 26^{\prime} 20^{\prime \prime}$ & 1720 \\
\hline 49 & Viborillas & Veracruz & $20^{\circ} 29^{\prime} 00^{\prime \prime}$ & $98^{\circ} 29^{\prime} 20^{\prime \prime}$ & 2200 \\
\hline 50 & Buenavista & Veracruz & $19^{\circ} 44^{\prime} 00^{\prime \prime}$ & $96^{\circ} 49^{\prime} 00^{\prime \prime}$ & 2150 \\
\hline 51 & Cerro La Tolva & Veracruz & $19^{\circ} 39^{\prime} 00^{\prime \prime}$ & $97^{\circ} 08^{\prime} 00^{\prime \prime}$ & 2000 \\
\hline 52 & Pueblo Viejo & Veracruz & $19^{\circ} 31^{\prime} 55^{\prime \prime}$ & $97^{\circ} 03^{\prime} 15^{\prime \prime}$ & 2140 \\
\hline 53 & El Encinal II & Veracruz & $19^{\circ} 31^{\prime} 16^{\prime \prime}$ & $97^{\circ} 03^{\prime} 08^{\prime \prime}$ & 2500 \\
\hline 54 & Rancho Las Golondrinas & Veracruz & $19^{\circ} 30^{\prime} 53^{\prime \prime}$ & $97^{\circ} 03^{\prime} 33^{\prime \prime}$ & 2649 \\
\hline 55 & Oxtlapa & Veracruz & $19^{\circ} 25^{\prime} 20^{\prime \prime}$ & $97^{\circ} 06^{\prime} 15^{\prime \prime}$ & 2140 \\
\hline 56 & El Rincón Atotonilco & Veracruz & $19^{\circ} 09^{\prime} 00^{\prime \prime}$ & $97^{\circ} 14^{\prime} 00^{\prime \prime}$ & 2500 \\
\hline 57 & Cerro Mirador (C. Hueso) & Oaxaca & $17^{\circ} 40^{\prime} 29^{\prime \prime}$ & $96^{\circ} 33^{\prime} 54^{\prime \prime}$ & 2400 \\
\hline 58 & Río Perfume-Oeste & Oaxaca & $17^{\circ} 39^{\prime} 00^{\prime \prime}$ & $96^{\circ} 32^{\prime} 00^{\prime \prime}$ & 2660 \\
\hline 59 & Río Perfume & Oaxaca & $17^{\circ} 38^{\prime} 49^{\prime \prime}$ & $96^{\circ} 32^{\prime} 26^{\prime \prime}$ & 2800 \\
\hline 60 & Puerto La Soledad & Oaxaca & $17^{\circ} 35^{\prime} 15^{\prime \prime}$ & $96^{\circ} 34^{\prime} 40^{\prime \prime}$ & 2500 \\
\hline 61 & Mirador & Oaxaca & $17^{\circ} 34^{\prime} 43^{\prime \prime}$ & $96^{\circ} 29^{\prime} 51^{\prime \prime}$ & 2800 \\
\hline 62 & Cerro Humo Chico & Oaxaca & $17^{\circ} 33^{\prime} 00^{\prime \prime}$ & $96^{\circ} 30^{\prime} 10^{\prime \prime}$ & 2800 \\
\hline 63 & Parte alta de la brecha & Oaxaca & $17^{\circ} 30^{\prime} 00^{\prime \prime}$ & $96^{\circ} 30^{\prime} 20^{\prime \prime}$ & 2950 \\
\hline 64 & El Carrizal & Oaxaca & $17^{\circ} 29^{\prime} 20^{\prime \prime}$ & $96^{\circ} 41^{\prime} 30^{\prime \prime}$ & 2540 \\
\hline 65 & Llano Verde & Oaxaca & $17^{\circ} 29^{\prime} 15^{\prime \prime}$ & $96^{\circ} 24^{\prime} 00^{\prime \prime}$ & 2200 \\
\hline 66 & Cruz de la Raya & Oaxaca & $17^{\circ} 18^{\prime} 00^{\prime \prime}$ & $96^{\circ} 19^{\prime} 00^{\prime \prime}$ & 2460 \\
\hline 67 & Tepitongo & Oaxaca & $17^{\circ} 18^{\prime} 00^{\prime \prime}$ & $96^{\circ} 02^{\prime} 00^{\prime \prime}$ & 1700 \\
\hline 68 & La Natividad & Oaxaca & $17^{\circ} 17^{\prime} 40^{\prime \prime}$ & $96^{\circ} 26^{\prime} 00^{\prime \prime}$ & 2.500 \\
\hline 69 & El Quelite & Oaxaca & $17^{\circ} 17^{\prime} 15^{\prime \prime}$ & $96^{\circ} 26^{\prime} 30^{\prime \prime}$ & 2372 \\
\hline 70 & Capulalpa-Llano Verde & Oaxaca & $17^{\circ} 11^{\prime} 30^{\prime \prime}$ & $96^{\circ} 22^{\prime} 44^{\prime \prime}$ & 2400 \\
\hline 71 & Cañada de Torres & Oaxaca & $17^{\circ} 11^{\prime} 03^{\prime \prime}$ & $96^{\circ} 22^{\prime} 44^{\prime \prime}$ & 2700 \\
\hline 72 & Cumbres de los Frailes & Oaxaca & $17^{\circ} 11^{\prime} 00^{\prime \prime}$ & $96^{\circ} 24^{\prime} 00^{\prime \prime}$ & 2500 \\
\hline 73 & Coapilla & Chiapas & $17^{\circ} 10^{\prime} 00^{\prime \prime}$ & $93^{\circ} 10^{\prime} 00^{\prime \prime}$ & 1750 \\
\hline 74 & Tenalchen & Chiapas & $16^{\circ} 37^{\prime} 00^{\prime \prime}$ & $93^{\circ} 20^{\prime} 00^{\prime \prime}$ & 2200 \\
\hline 75 & Jocosic & Chiapas & $16^{\circ} 50^{\prime} 00^{\prime \prime}$ & $92^{\circ} 30^{\prime} 00^{\prime \prime}$ & 2300 \\
\hline
\end{tabular}

Table 2. Number of trees and conservation condition of $\mathrm{T}$. globosa in Mexico.

\begin{tabular}{llll}
\hline $\mathbf{N}^{\mathbf{0}}$ & Population & Mature trees & Condition \\
\hline 1 & La Ciénega & 27 & inadequate \\
2 & El Manzano & 9 & unfavorable \\
3 & El Manzano-VitroParque & 162 & favorable \\
4 & El Tejocote & 436 & favorable \\
5 & La Camotera & 100 & inadequate \\
6 & Cañada La Trinidad & 208 & favorable \\
7 & La Trinidad & 106 & favorable \\
8 & Potrero redondo & 3460 & favorable \\
9 & Cañada La Era & 657 & favorable \\
10 & La Yerbabuena & 357 & favorable \\
\hline
\end{tabular}

\begin{tabular}{llll}
\hline $\mathbf{N}^{\mathbf{0}}$ & Population & Mature trees & Condition \\
\hline 11 & La Encantada & 543 & favorable \\
12 & La Tinaja (Cañada) & 3,035 & favorable \\
13 & Reserva "El Cielo" & 100 & inadequate \\
14 & Mesas de San Isidro & 123 & unfavorable \\
15 & Cañada de las Avispas & 330 & favorable \\
16 & La Joya del Hielo & 2 & unfavorable \\
17 & Cañada Los Granadillos & 120 & inadequate \\
18 & Barranca El Bosque & 4 & unfavorable \\
19 & Cañada de Agua Fría & 55 & unfavorable \\
20 & Los Corrales-El Chico & 57 & unfavorable \\
21 & Cañada Los Zorrillos & 41 & inadequate \\
22 & Cañada Los Ayacahuites & 153 & favorable \\
\hline
\end{tabular}




\begin{tabular}{llll}
\hline $\mathbf{N}^{\mathbf{0}}$ & Population & Mature trees & Condition \\
\hline 23 & Pueblo Nuevo & 166 & favorable \\
24 & El Remudadero & 10 & unfavorable \\
25 & Cuyamalolla & 110 & unfavorable \\
26 & El Encinal II & 90 & unfavorable \\
27 & Barranca de la Funda & 5 & unfavorable \\
28 & Capulalpa & 11 & unfavorable \\
29 & Cañada de Torres & 45 & unfavorable \\
\hline
\end{tabular}

As noted above, the environments inhabited by $T$. globosa are characterized as moist microhabitats covered by an upper canopy formed by other species of larger size. This protecting cover could also serve as a bird perch accounting for the large number of yew juveniles thriving vigorously at short distances from adults of spruce, oak, pine, true fir (Figure 2) and to a lesser extent, from the existing yew adult individuals as seen in different species by other authors [18, 19]. Before the creation of new seedlings, the action of different dispersants is needed to make a decisive contribution to effective aril dispersal [20]. This means that the use as food of the few available arils could lead to the observed high recruitment rates. Thus, well-preserved, Mexican temperate forests are ecosystems with considerable capacity to shelter both forestresident birds and bird species migrating through the Americas. From observations at Las Tinajas Mountain, Bluebirds (Sialia currucoides) eating yew arils during the fall have been detected (pers.obs.), which is likely complemented by the presence of other Turdidae birds - a very important family for yew dispersal - such as the Aztec Thrush (Ridgwayia pinicola), the Brown-backed Solitaire (Myadestes occidentalis), the Black Thrush (Turdus infuscatus) and the Clay-colored Trush (Turdus grayi) which are present in northern forestland communities of the Sierra Madre Oriental [21]. It is unknown whether there is some involvement in $T$. globosa dispersal by terrestrial mammals (foxes, badgers, weasels, etc.). On the other hand, hydrochory dispersal events should not be ruled out, due to the sub-riparian character of the species. We have not detected mechanical protection systems provided by other species (plant-plant mutualistic interactions) acting over young yew seedlings existing in the prospected area sensu García \& Obeso [18].

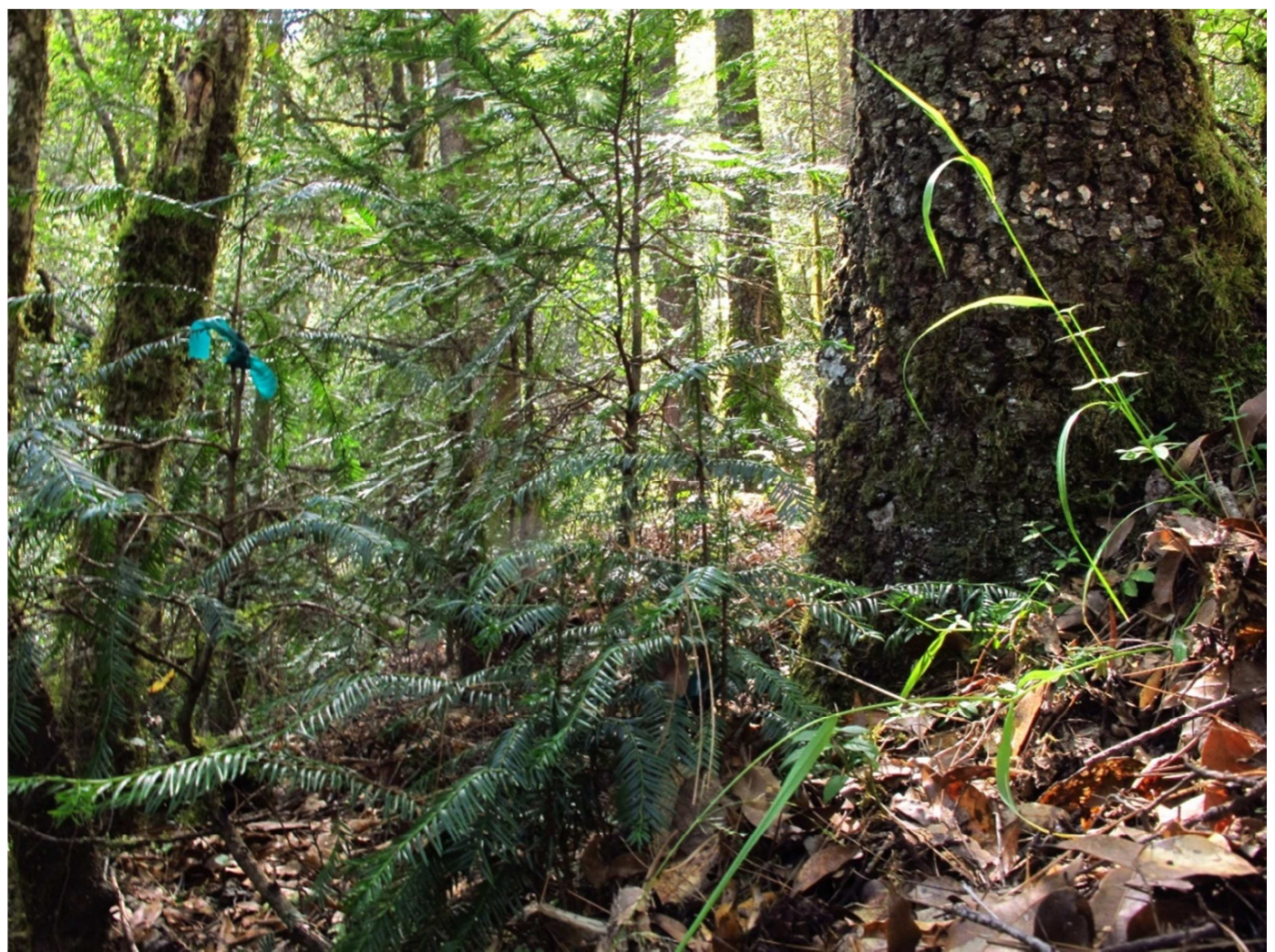

Figure 2. Juvenile yew growing beside an Abies religiosa. Promotion of hanger effect by the canopy individuals is very common in order to facilitate the recruitment of new plants.

The other location was chosen because it contains burgeoning yew stands situated at Los Ayacahuites Gully within El Chico National Park. This fact represents an a priori major figure of protection. This territory has vast formations of Abies religiosa and several pine species in the lower levels and is one of the oldest forest reserves in Mexico. Also, particularly characteristic, the park's managers have a special awareness of Mexican Yew. In addition, for years, it has been the preferred area for the study of the species $[15,16,17]$.
However, the Protected Natural Areas do not cover or guarantee the protection of $T$. globosa and its associated ecosystems across its distribution [22]. In addition, even in areas where the Mexican yew has been until recently regarded as abundant, the species may now be suffering a reversal or at least a collapse in regeneration dynamics within its populations. This is the case of some nuclei present in the Sierra Gorda Biosphere Reserve in Queretaro (Figure 3), where we observed an aging population in Los Granadillos 
Gully and Agua Fría Gully, for example; this is due to increased livestock pressure and the cutting down of dozens of adult individuals. Paradoxically, some kilometres away, in Las Avispas Gully, there is an important yew nucleus-area managed by another communal group, different than that above, where the owner is aware of the environmental value of their surroundings.

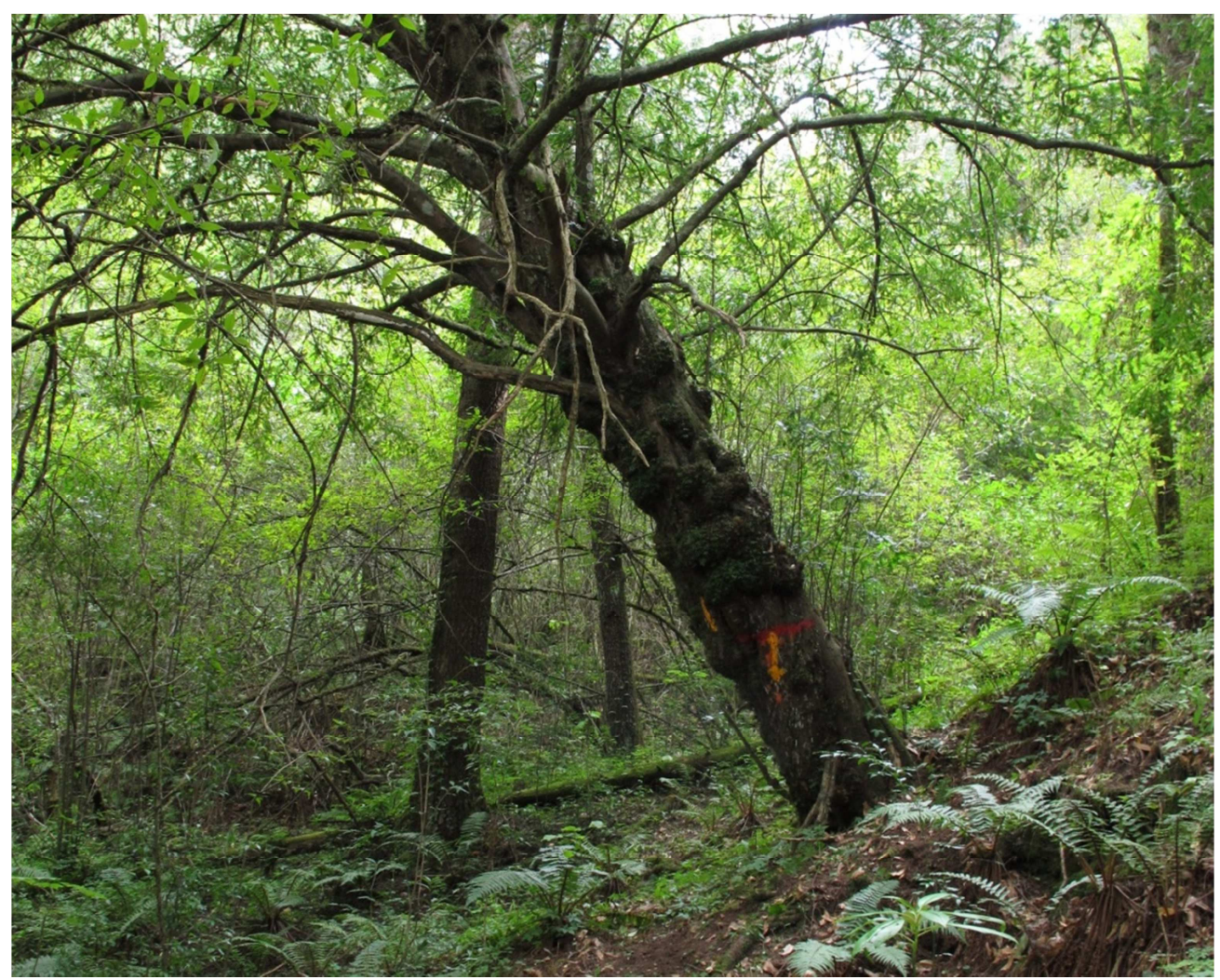

Figure 3. Female tree of T. globosa characterized in Sierra Gorda. Queretaro. Mexico.

\subsection{Importance of the Local Communities Implication}

An obvious and predictable fact is that to promote optimal stability dynamics of this valuable yew stands needs the indispensable involvement of the existing human communities for conservation of the natural environment. In La Encantada Communal Land in Nuevo León - where, among others, the burgeoning yew population of Las Tinajas occurs - it is revealing to observe the management of the existing forest resources, which includes major logging of pines and oak species. However, this management is far less widespread throughout the whole territory; despite forest management by the community being a deeply-rooted custom, the reality of Mexican forests managed by local people is uneven and complex [23]. It has been highlighted that many human customs are the main limiting factor for the effective regeneration of the species. Consequently, most populations consist of adult specimens roughly dispersed in areas generally affected by disturbances such as timber extraction and excessive pressure by domestic cattle.

There are many voices warning about increased disappearance of these ecosystems in the American biogeographic and trans-frontier region known as Mega-Mexico, which is one of the global hotspots of biodiversity [24]. In recent decades, the deforestation problem has done nothing but worsen alarmingly: the area occupied by these cloud-forest formations has fallen by at least, $50 \%$ according to the National Commission for Knowledge and Use of Biodiversity-Conabio. Anthropic causes are clandestine and uncontrolled clear-cutting for wood extraction, recurrent forest fires and land-use changes generally for agriculture and livestock purposes [23]. To date, this increasing level of threat has been the major cause of decline of this unknown yew. Local extinction of the species has likely happened in the State of Mexico, where there are herbarium yew samples from the mid-20 ${ }^{\text {th }}$ century [9]. Recent disappearance of already isolated and fragmented populations has been noticed near to the northern El Cielo Reserve in Tamaulipas, in addition to the loss of a large number of individuals - only stumps remain - within some forests of Veracruz and Hidalgo. Both these previously mentioned Mexican States contain a high level of biodiversity; and in this sense, they are significantly affected by the relentless deforestation. A study of Contreras-Medinaet al. [25] has analyzed, through predictive modelling, habitats housing yews in a macro-territorial way: since a few decades ago, the potential niche of $T$. globosa has probably disappeared by up to $80 \%$ in the last forty years.

\subsection{Therapeutic Properties. Taxanes and T. globosa}

As is known, yew is a potent anticancer agent. In the last 
two decades, studies of its biomedical properties have been extended to the Mesoamerican species [26]. Paradoxically, beginning forty years ago, this therapeutic attribute is reducing the populations of different species from the Taxus genus throughout North America; also, more recently, the Asian yew is decreasing even more dramatically in a pressing manner [27].

In Mexico, T. globosa populations do not seem to be currently significantly affected by this type of exploitation, except in El Tejocotal town, in Nuevo Leon (perhaps due to its easy access and its proximity to Monterrey City). However, this is possibly changing due to the growing demand for taxol intended for the global pharmaceutical industry. In other regions, there have been reports of selective extraction of yew in some Guatemalan forests [7]. Detailed and updated studies of the demographic situation of the species in the three Central American countries (Guatemala, Honduras and El Salvador) show high rates of deforestation and loss of biodiversity are happening. In our opinion, given the small size of the populations and their restricted global distribution, the commercial exploitation of the species will lead to rapid extinction in the short term. In this regard, T. globosa is included in the Official Mexican Norm (NOM-59-ECOL-2010) under its "in special protection" category [27]; and, in Guatemala, it appears in Conap [29] within the list of species requiring an environmental impact study before its possible use (included in Category 2 of the Red List of forest species). However, the economic incentive that will encourage plant extraction by certain members of local communities with high levels of marginality could be the trigger of illegal and uncontrolled exploitation, as is widespread in Asia [31].

\section{Conclusions}

In the 29 populations characterized in Mexico, 15 had a favourable conservation status, two an inadequate state and 12 populations are in unfavourable conditions. The region where T. globosa is best represented and best preserved is the Mexican state of Nuevo León followed by Hidalgo. In this sense, biggest problems of threat such as fragmentation and habitat degradation, low number of breeding individuals, and land use change is observed in a north-south gradient. Different authors confirm this spatial trend in the remaining populations of Guatemala, El Salvador and Honduras [7, 9]. The poor fruit production suggests that the species may be subject to both inter-annual pulses of regeneration and there is a population requirement for a minimum number of adult individuals with an adequate sex ratio in order to achieve effective pollination and minimum fructification rates. This phenomenon has been confirmed in studies conducted in $T$. baccata [34]. A deeper and specific research on autoecology of $T$. globosa is needed.

In summary, our preliminary diagnosis suggests that well-preserved Mexican Yew could match the following pattern: i) a need for a strong contingent of reproductive individuals to counteract the low fruit production per adult individual due to innate abiotic factors of its autecology, ii) the existence of a protective canopy against direct sunlight that also provides the perch effect of other tree species, iii) the need of positive interactions with frugivore dispersing birds and low pressure by herbivore species. Therefore, for satisfactory renewal of $T$. globosa formations, the existence of a heterogeneous, fully structured and minimally altered ecosystem is essential.

In order to mitigate the human pressure, a possible solution to boost preservation of some of the most vulnerable and accessible yew stands could be the setting up of green pathways which could serve both as touristic attractions and to bring sustainable income to the local communities currently managing these areas, as can be observed in the population of Las Viborillas (Veracruz).

Different strategies to improve the knowledge of ecological behaviour are needed. The main objective is to mitigate - or avoid in the best of cases - the threats described above; so that, multifunctional action planning includes the in situ characterization and conservation of existing populations, the active promotion of genetic diversity by creating living collections and ex situ seed sources for reproduction, and the progress in biomedical research in order to reduce provisioning problem by exploiting the wild yew. Multidisciplinary collab oration between institutions and working groups are becoming increasingly necessary. In the case of T. globosa, this cooperation has allowed the use of some of the techniques successfully applied in the active conservation of T. baccata in the Mediterranean area [30], because although large distances exist between the two species, the reality and necessity of conservation is the same.

\section{Acknowledgements}

We thank to Dra. Lidia Osuna (CIBISS-IMSS) for their help during the field work. Dr. Pablo Ferrer (CIEF- Valencia) improved an early version of this manuscript. Dr. Peter Thomas (Keele University) looked over the English version of this manuscript.

\section{References}

[1] E. A. Cope, "Taxaceae: The Genera and cultivated species", The Bot. Rev., 1998, vol. 64(4), pp. 291-322.

[2] R. Spjut, "A Revised Taxonomic Key to the Species and Varieties of Taxus (Taxaceae)", Annual Meeting of the Botanical Society of America. Oregon Convention Center. Portland, Oregon. 2000

[3] A. M. Redmond,"Population ecology of Taxus floridana (Nutt.), a dioecious, understory tree", Thesis, Florida State University, 1984, p. 47.

[4] S. Zamudio, "Familia Taxaceae. In: Flora delBajío y de regionesadyacentes", Instituto de Ecología Pátzcuaro, Michoacán, México. Fascículo 9. 1992, p. 7.

[5] R. Contreras-Medina and I. Luna, "Presencia de Taxus globosa Schltdl. (Taxaceae) en el Estado de Chiapas, México", Polibotánica, 2001, vol. 12, pp. 51-56. 
[6] P. C. Standley and J. A. Steyermark, "Taxaceae" In: Flora of Guatemala. Fieldiana Botany, 1958, vol. 24, pp. 60-63.

[7] J. C. Rosito,"Estudio florístico de lacomunidaddelcipresillo (Taxus globosa Schltdl.) enlos cerros Pinalón, Guaxabajá y MululjáenlaSierra de Las Minas. Tesis de Licenciatura, Universidad de San Carlos de Guatemala,1999, p.106.

[8] J. Silba, "An international census of the Coniferae, I." Phytologia Memoria,1984, vol. 7, pp.1-79.

[9] M. J. Shemluck, E. Estrada, R. Nicholson and S. W. Brobst, “A preliminary study of the taxane chemistry and natural history of the Mexican yew, Taxus globosa Schltdl." Boletín de la Sociedad Botánica de México,2003, vol. 72, pp. 119-127.

[10] S. Cortés, F. Vasco and E. Blanco, "El Libro del Tejo". ARBA. 2000 .

[11] J. Charco, "El tejo en el norte de África". In: El tejo en el Mediterráneo Occidental (L. Serra, ed.), 1:177-185. Conselleria de Territori i Habitatge. Ministerio de Medio Ambiente. CAM, 2007.

[12] J. Rzedowski,"Vegetación de México",Limusa,Ciudad de México,1978.

[13] I. Luna-Vega, S. Ocequeda-Cruz and O. Alcántara-Ayala,"Florística y notas biogeográficas del bosque mesófilo de montaña del Municipio de Tlanchinol. Hidalgo. México", Anales de Instituto de Biología. Serie. Botánica, UNAM, Mex., 1994, vol. 65, pp. 31-62.

[14] M. A. García-Aranda, A. E. Estrada-Castillón, E. Jurado-Ybarra and D. U. González-Uribe, 2011,“Análisis de once poblaciones naturales de Taxus globosa en la Sierra Madre Oriental" Madera y Bosques,vol. 17, pp. 93-104.

[15] M. Soto- Hernádez, J. López-Upton, J. J. Vargas-Hernández, L. Muñoz-Gutiérrez and R. San Miguel, "Estado de conservación de Taxus globosa en México”Spanish J. Rural Dev., 2011, vol.2, pp. 61-68.

[16] F. Zavala-Chávez, “Análisis demográfico preliminar de Taxus globosa Schlecht. en el Parque Nacional El Chico, Hidalgo, México. II: Población de adultos y algunas características del hábitat", Ciencia Ergo Sum (México), 2001, vol. 8, pp. 166-174.

[17] S. E. Ramírez-Sánchez, J. López-Upton, G. García-De los Santos, A. Hernández-Livera , O. J. Ayala-Garayand J. J. Vargas-Hernández, "Caracterización morfológica, análisis de imágenes de semillas y latenciaen dos poblaciones de Taxus globosaSchltdl.”, Revista Fitotécnia Mexicana, 2011, vol. 34, pp. 93-99.

[18] D. García and J. R. Obeso, "Facilitation by herbivore- mediated nurse plants in a threatened tree, Taxus baccata: local effects and landscape level consistency", Ecography, 2003, vol. 26, pp. 739-750.

[19] P. A. Thomas and A. Polwart, "Biological flora of the British Isles. Taxus baccata L.”,J. Ecol., 2003, vol. 91, pp. 489-524.

[20] P. Jordano, C. García, J. A. Godoy and J. L. García-Castaño, "Differential contribution of frugivores to complex seed dispersal patterns. Proceedings of the National Academy of Science, 2007, vol. 104, pp. 3278-3282.

[21] R. Pedraza, "Conservación de la Avifaunaenla Reserva de la Biosfera Sierra Gorda; del Pago de Servicios Ambientales a la Educación Ambiental", In: Proceedings of the Fourth International Partners in Flight Conference: Tundra to Tropics, 2009, pp. 569-576.
[22] R. Contreras- Medina, I. Luna- Vega and J. RamírezMartínez,"Representatividad del tejo (Taxus globosa Schltdl.) en las áreas naturales protegidas de Mesoamérica", Spanish J. Rural Dev., 2010, vol. 1, pp. 51-60.

[23] CONABIO,“El Bosque Mesófilo de Montaña en México: Amenazas y Oportunidades para su Conservación y Manejo Sostenible", Comisión Nacional para el Conocimiento y Uso de la Biodiversidad. México. 2010, pp. 1-197.

[24] T. P. Ramamoorthy, R. Bye, A. Lotaand J. Fa,"Diversidad biológica de México; Orígenes y distribución. Oxford University Press, Nueva York, 2003.

[25] R. Contreras-Medina, I. Luna-Vega and C. Ríos-Muñoz, "Distribución de HYPERLINK "http://www.biologia.unam.mx/biolevol/ilv/2010_contrerasetal _Taxus.pdf"TaxusHYPERLINK

"http://www.biologia.unam.mx/biolevol/ilv/2010 contrerasetal Taxus.pdf" globosaHYPERLINK "http://www.biologia.unam.mx/biolevol/ilv/2010 contrerasetal Taxus.pdf" (HYPERLINK

"http://www.biologia.unam.mx/biolevol/ilv/2010 contrerasetal Taxus.pdf"TaxaceaeHYPERLINK

"http://www.biologia.unam.mx/biolevol/ilv/2010 contrerasetal Taxus.pdf") en México: Modelos ecológicos de nicho, efectos del cambio del uso de suelo y conservación", Revista Chilena de Historia Natural, 2010, vol. 83, pp. 421-433.

[26] M. Soto-Hernández, M. Sanjurjo, M. A. González-Garza, D. Cruz-Veja and F. Giral-González, "EI Tejo mexicano (Taxus globosa Schl.), potencial de suaprovechamientoentaxol", Ciencia Ergo Sum (Mexico), 2003, vol. 7, pp. 277-279.

[27] C. Blanché, "El teix: Biodiversitat per a la salud", In: II Jornades sobre el Teix a la Mediterrània Occidental. Institutd'EstudisCatalans. Institució Catalana d'Història Natural, 2011, vol. 130 , pp. 5-7.

[28] SEMARNAT (Secretaría de Medio Ambiente y Recursos Naturales), "Norma Oficial Mexicana NOM-059-ECOL-2010, Protección ambiental -Especies nativas de México y de flora y fauna silvestres- Categorías de riesgo y especificaciones para suinclusión, exclusión o cambio- Lista de especiesenriesgo", Diario Oficial de laFederación. México, 30 de diciembre. 2010.

[29] CONAP (Consejo Nacional de Áreas Protegidas),"Listado de especies protegidas amenazadas de extinción”, Resolución No. ALC/028- del Consejo Nacional de Áreas Protegidas, Guatemala, 2001, pp. 21-55.

[30] X. García-Martí, "Producción de material forestal de T. baccata L. destinado a planes de conservación", In: El Tejo en el Mediterráneo Occidental. Luis Serra (Ed). Generalitat Valenciana-CAM. 2007, vol. 1, pp.141-152.

[31] G. Nimachow, J. S. Rawat and Monpa community, "Vanishing Anti-cancer Yews: A study in West Kameng District of Arunachal Pradesh, India”. Spanish J. Rural Dev., 2011, Supplement 2, Vol. 2, pp. 43-50.

[32] J. Svenning, E. Maga ${ }^{\circ}$ rd, "Population ecology and conservation status of the last natural population of English yew Taxus baccata in Denmark", Biol. Conserv. 1999, vol. 88(2), pp.173-182.

[33] L. Serra, "9580* Bosques mediterráneos de Taxus baccata (*)". In: V. V. A. A., Bases ecológicas preliminares para la conservación de los tipos de hábitat de interés comunitario en España. Madrid: Ministerio de Medio Ambiente y Medio Rural y Marino. 2009. p. 6. 
88 Javier López-Upton and Xavier Garcia-Martí: Taxus globosa Schltdl. (Taxaceae). Distribution and Diagnosis of an Endangered Yew

[34] R. Sanz, F Pulido, D Nogués-Bravo. Predicting mechanisms across scales: amplified effects of abiotic constraints on the recruitment of yew (Taxus baccata)", Ecography, 2009, vol. 32, pp. 993-1000. 